Trawlermen have a fatalistic attitude to sickness and death and pay little attention to safety devices or their own sickness. Health education is needed, and an industrial medical officer should also supervise the first-aid training of skippers and mates, who should attend courses throughout their period of service at sea.

The health and safety of trawlermen are still the subject of much public concern. The interim report of the Board of Trade's Committee of Inquiry which was set up after last winter's three trawler disasters recommended the provision of a support ship to the fishing fleet in the area north of Iceland. The Orsinoe has been at sea throughout the winter carrying meteorological staff, a medical officer, and sick berth attendant, and the results of this innovation will be of great interest ; but only when real changes have been made in conditions at sea will there be a fall in the excessively high mortality rate of fishermen.

\section{Boarding Out}

The adverse effect on patients of prolonged care in large institutions is now well established. Thus it was hardly surprising that the Royal Commission on the Law Relating to Mental Illness and Mental Deficiency, 1957, looked critically on the mental hospitals and supported the concept of community care. The Mental Health Act, 1959, led to the establishment by local health authorities of various types of accommodation for the mentally disordered, including longstay psycho-geriatric hostels, ${ }^{1}$ short-stay hostels, ${ }^{2}$ and boarding out with private landladies. The last practice was not new. Indeed, in 1856 Bucknill, at Devon County Lunatic Asylum, instituted such a scheme for the mentally ill, based on the considerably older system at Gheel in Belgium, and for many years voluntary organizations like the Guardianship Society and the Mental After-care Association had boarded out both the mentally ill and the mentally subnormal.

In his annual report for 1967 the medical officer of health for Exeter ${ }^{3}$ states that many mentally disordered persons may be placed in lodgings provided the landladies are chosen with care and adequate social work support is given. In that city in 1967 there were 112 such people in lodgings, about half of whom were in open employment. Difficulties arose over the low wage obtained ( $£ 6-£ 7$ a week) and the cost of lodgings ( $£ 55 \mathrm{~s}$. a week.) These difficulties have been overcome at Croydon ${ }^{4}$ by the local authority subsidizing the rent of the patients living with private landladies. There a wholetime boarding-out officer was appointed in 1962, whose job was to assess accommodation and match the landlady to the patient. The latter paid directly to the landlady a contribution to his rent assessed according to means, and the local authority made up the difference. In the period 1962 to 1965, 120 patients were placed, and the average total cost

\footnotetext{
1 Jones, K. S., and Milne, V. M., Brit. Hosp. F. soc. Serv. Rev., 1966, 76, 159.

2 Morgan, P., Mth. Bull. Minist. Hlth Lab. Serv., 1964, 23, 224.

Annual Report of the Medical Officer of Health for 1967, Exeter. 1968.

- Wright, S. L., Publ. Hlth (Lond.), 1966, 80, 164.

Brown, G. W., Monck, E. M., Carstairs, G. M., and Wing, J. K., Brit. f. prev. soc. Med., $1962,16,55$.

Report of Committee on Local Authority and Allied Personal Social Services, para. 340 , 1968. H.M.S.O.

- Laugharne, J. R. Case Conference and A.S.W. News, 14, 350.
}

to the local authority, including administration, was $£ 27 \mathrm{~s}$. a week per patient.

Fortunately the majority of patients discharged from mental hospitals live at home with their relatives, though it has been suggested that some patients suffering from schizophrenia might be better living with strangers. ${ }^{5}$ If boardingout schemes are to be extended, there must be close supervision of both landlady and patient by social workers who are part of a joint social work team serving both the hospital and local authority, otherwise prompt return to hospital for any patient who relapses and needs attention will not be available. As the Seebohm report recently emphasized, "There must be no danger of neglect outside the hospital replacing the imaginative and skilful care now provided inside many of them."s But, since the same report recommends that responsibility for community social services for the mentally disordered should be included in the proposed new social services department, it is difficult to see how adequate liaison with the hospital will be maintained.

Any large-scale expansion of boarding-out of the mentally handicapped must be viewed critically, for much Victorian mental-health legislation was inspired to control the abuse of the "private mad-house" system. But in view of the problems of child care officers in finding homes for normal children $^{7}$ it seems unlikely that there will be any great demand from landladies for middle-aged mentally handicapped lodgers.

\section{Centenarius Scandinavicus}

Bursting with the spirit of inquiry into natural phenomena, the European countries in the nineteenth century saw the foundation of many journals to record the new and exciting observations. Some of these publications still survive, often with a change of title, a greater girth, a more recondite content, and, such is the toll of time, a new editor. Now joining the Lancet and the B.M.F. as a centenarian is the journal we know as Acta Medica Scandinavica, which began in 1869 as Nordiskt Mediciniskt Arkiv.

The founder and first editor of the journal was Axel Key, professor of pathological anatomy at the Karolinska Institute in Stockholm. According to an account of his work in the current issue $^{1}$ he thought the institute was somewhat overshadowed by the universities, notably Uppsala, and that a journal to publish the papers of its members would stimulate them to scientific activity. Such a reason for founding a journal seems entirely appropriate to those spacious days, though now so many pour from the presses that to start one for which there is not an established need is more likely to deserve censure than commendation. However, it was thought that " the incentive would then exist for one and all to provide matter for the journal, and failure to do so would be felt as a neglect of duty." So in 1863 a journal called Medicinskt Arkiv, of which Key was one of three editors, began publication of papers from the institute.

But Key soon had bigger plans and began to think about a journal for all the Scandinavian countries. This idea won support at a meeting in 1868, and the following year saw the closure of the old journal and the birth of its successor,

\footnotetext{
1 Strandell, B., Acta med. scand., 1969, 185, 1.
} 